\title{
Influence of Zinc on Functioning of Anti-oxidant Enzymes and Zinc content in Hogland Solution of Rice Genotypes
}

\author{
Venkatesh Dore*, R.V. Koti and C.M. Nawalgatti \\ Department of Crop Physiology, College of Agriculture, UAS Dharwad, India \\ *Corresponding author
}

\begin{abstract}
A B S T R A C T

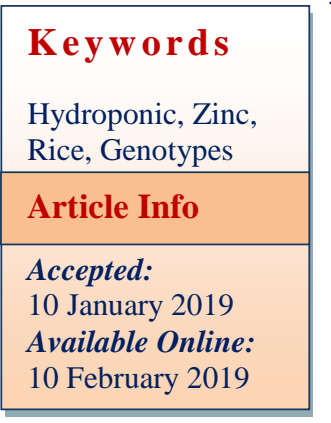

Hydroponic experiment was carried out to analyse the effect of $\mathrm{Zn}$ on anti oxidative enzyme activity, zinc content in shoot and root of rice genotypes and zinc efficiency. The experiment was comprised of 20 genotypes and two treatments viz., T1: $0.01 \mu \mathrm{M}(\mathrm{Zn}$ deficient); T2: $2.0 \mu \mathrm{M}$ (Zn-sufficient/control). Results indicated $2.0 \mu \mathrm{M}$ concentration of zinc sulphate significanty incresead the zinc content in shoot (10.6 ppm) and root (18.8 $\mathrm{ppm})$, superoxide dismutase enzyme $\left(12.8 \mathrm{~g}^{-1}\right.$ protien $\left.^{-1}\right)$ and perioxidase enzyme activity $\left(4.21 \mu \mathrm{mol} \mathrm{min}^{-1} \mathrm{~g}^{-1}\right.$ protein) were measured on 4-week old seedlings. Screening of $\mathrm{Zn}$ efficient genotypes carried out in hydroponic experiment, Halga and Kalanamk and Dodigya was recorded as most Zn-efficient genotypes, however Koorigenellu was found as $\mathrm{Zn}$-inefficient genotype with respect to shoot dry weight.
\end{abstract}

\section{Introduction}

India has a long history of rice cultivation. Globally, it stands first in rice area and second in rice production, after China. It contributes 21.5 per cent of global rice production. Within the country, rice occupies one-quarter of the total cropped area, contributes about 40 to 43 per cent of total food grain production and continues to play a vital role in the national food and livelihood security system (Anon, 2008).

Zinc ( $\mathrm{Zn})$ is an essential element in all organisms. In oxidized $\mathrm{Zn}$ (II) form, it is found throughout biology, it acts as a catalytic or structural co-factor in a large number of enzymes and regulatory proteins (Maret,
2009). Well known examples in plants include the enzymes carbonic anhydrase and alcohol dehydrogenase, and the structural $\mathrm{Zn}$ finger domains mediating DNA-binding of transcription factors and protein-protein interactions. Zinc $(\mathrm{Zn})$ deficiency is major constraint to rice production. To overcome these nutritional constraints it comes at substantial cost to farmers and the efficiency of fertilizer use is low. Breeding crops that are efficient at acquiring $\mathrm{Zn}$ from native soil reserves or fertilizer sources has been advocated as a cost-effective solution.

Zinc (Zn) deficiency is one of the most critical global health problems because rice is the main staple food of Asia. Affecting nearly one-third of world population (Welch and 
Graham, 2004; Hotz and Brown, 2004). Low dietary $\mathrm{Zn}$ intake is considered to be the major reason for widespread occurrence of $\mathrm{Zn}$ deficiency in human populations, especially in developing countries. Over $30 \%$ of the world's population may suffer from zinc deficiency (Welch et al., 2005). Zn deficiency is especially prevalent among resource-poor women and children.

Zinc has multiple roles in basic cellular functions in all living organisms and is required for the normal development and functioning of non-specific and acquired immunity in humans (Shankar and Prasad, 1998). People who suffer from severe zinc deficiency show stunted growth, have slowly healing wounds, and become mentally retarded (Prasad and Bose, 2001). Yet, the most common deficiencies are of a less dramatic nature and lead to slight stunting, poorer mental development and poor immune system functioning. In China, average intake of zinc is $85.6 \%$ of its Recommended Dietary Allowance (RDA), and in Gansu province, the average intake of zinc is only $64.8 \%$ of the RDA (Ger et al., 1996).

Genotypes of crop plants can vary widely in $\mathrm{ZE}$, as reported for wheat (Cakmak et al., 2001), common bean (Hacisalihoglu et al., 2004) and rice (Sakal et al., 1987). Mechanisms responsible for genotypic variation in $\mathrm{ZE}$ were thoroughly reviewed by Rengel (2001) and Hacisalihoglu and Kochian (2003). There seem to be many uncertainties on mechanisms that control tolerance to $\mathrm{Zn}$ deficiency. Most likely, there is no single mechanism in any crop species. The expression of high $\mathrm{ZE}$ in cereals including rice, wheat, rye, barley, triticale and oat was related to enhanced uptake and translocation capacity of $\mathrm{Zn}$ into shoots and higher amounts of physiologically active $\mathrm{Zn}$ in leaf tissues (Cakmak et al., 1997).
Among the different screening methods, hydroponic culture has often been used for screening for tolerance to mineral deficiency and toxicity. Screening in hydroponic culture allows for rapid screening, it overcomes seasonal effects and provides disease free conditions (Dragonuk et al., 1989). A number of different wheat genotypes have been screened for their response to low $\mathrm{Zn}$ in $\mathrm{Zn}$ deficiency calcareous soil and significant different in Zn efficiency have been consistently found among few genotypes in both field and growth chamber experiments (Cakmak et al., 1999; Hacisalihoglu et al., 2001).

The overall aim of the study is to understand the effect of contrasting solution $\mathrm{Zn}$ concentrations on growth of rice genotypes, biophysical parameters and zinc uptake by shoot and root of rice genotypes.

\section{Materials and Methods}

The experiment was carried during 2016 at Department of Crop Physiology, College of Agriculture, UAS, Dharwad. Before growing, seeds were surface sterilised in 70 per cent ethanol and 5 per cent sodium hypochlorite for 1 and $15 \mathrm{~min}$, respectively. Seeds were then rinsed five times in deionised water. Seeds were germinated on moist filter paper wetted with deionised water for 3-4 days in the dark at room temperature. Only healthy and uniform seedlings were transplanted to solution culture.

A basal nutrient solution (Hoagland and Arnon, 1950; Pandey et al., 2012) was used with the following nutrient concentrations (mM): $\mathrm{KNO}_{3}$ (16000), $\mathrm{Ca}$ (NO3) $2.4 \mathrm{H}_{2} \mathrm{O}$ (6000), $\quad \mathrm{NH}_{4} \mathrm{H}_{2} \mathrm{PO}_{4} \quad$ (4000), $\quad \mathrm{MgSO}_{4} \cdot 7 \mathrm{H}_{2} \mathrm{O}$ (2000), $\mathrm{KCl}$ (50), $\mathrm{H}_{3} \mathrm{BO}_{3}$ (25), Fe-EDTA (25), $\mathrm{MnSO}_{4} . \quad 4 \mathrm{H}_{2} \mathrm{O}$ (2), $\mathrm{Na}_{2} \mathrm{MoO}_{4} \cdot 2 \mathrm{H}_{2} \mathrm{O}$ (0.5), $\mathrm{CuSO}_{4} .5 \mathrm{H}_{2} \mathrm{O}(0.5)$ and $\mathrm{Zn}$ as $\mathrm{ZnSO}_{4}$ at two levels viz. 0.01 (Zn-deficient) and 2.0 $\mathrm{mM}$ (Zn-sufficient/control) (Plate 1). 
The nutrient solution was aerated continuously and replaced at 5 days interval. Target $\mathrm{pH}$ values ( $\mathrm{pH}$ 5.5) were obtained by titrating the basal solution with $\mathrm{KOH}$ or $\mathrm{H}_{2} \mathrm{SO}_{4}$. Plants were grown in $2 \mathrm{~L}$ of aerated solution and the environment was strictly maintained under $10 \mathrm{~h}$ light and $14 \mathrm{~h}$ dark (550-560 $\mathrm{mmol} \mathrm{s}^{-1}$ per $\mathrm{mA}$ ).

The activity of SOD was assayed by measuring its ability to inhibit the photochemical reduction of nitro blue tetrazolium (NBT) using the method of Beauchamp and Fridovich (1971). The reaction mixture contained $100 \mathrm{~mL} 1 \mathrm{mM}$ riboflavin, $100 \mathrm{~mL} 12 \mathrm{mML}$-methionine, 100 $\mathrm{mL} 0.1 \mathrm{mM}$ EDTA (pH 7.8), $100 \mathrm{~mL} 50 \mathrm{mM}$ $\mathrm{Na}^{2} \mathrm{CO}^{3}$ (pH 10.2) and $100 \mathrm{~mL} 75 \mathrm{mM}$ nitroblue tetrazolium (NBT) in $2,300 \mathrm{~mL} 25$ $\mathrm{mM}$ sodium phosphate buffer $(\mathrm{pH} 6.8$ ), with $200 \mathrm{~mL}$ crude enzyme extract in a final volume of $3 \mathrm{~mL}$. SOD activity was assayed by measuring the ability of the enzyme extract to inhibit the photochemical reduction of NBT. Glass test tubes containing the mixture were illuminated with a fluorescent lamp (120 W); identical tubes that were not illuminated served as blanks. After illumination for 15 min, the absorbance was measured at $560 \mathrm{~nm}$. One unit of SOD was defined as the amount of enzyme activity that was able to inhibit by 50 per cent the photoreduction of NBT to blue formazan. The SOD activity of the extract was expressed as SOD unit $\mathrm{g}^{-1}$ protein.

Peroxidase activity was estimated following the method of Mahadevan and Sridhar (1986) with some modifications. Three $\mathrm{ml}$ of buffer solution, $0.05 \mathrm{ml}$ guaiacol solution, $0.1 \mathrm{ml}$ enzyme extract and $0.03 \mathrm{ml}$ hydrogen peroxide solution were pipetted into a cuvette. The absorbance was adjusted to zero at 436 $\mathrm{nm}$ in a UV-Vis spectrophotometer. The change in absorbance was noted at an interval of 20 seconds after adding $0.5 \mathrm{ml}$ of two per cent $\mathrm{H}_{2} \mathrm{O}_{2}$ (Hydrogen peroxide). The enzyme activity was expressed as change in absorbance (DOD) $\mu \mathrm{mol} \mathrm{min} \mathrm{g}^{-1} \mathrm{~g}^{-1}$ protein.

$\mathrm{Zn}$ concentration was analyzed in shoot and root. Samples were pre-digested by adding ten $\mathrm{ml}$ of concentrated nitric acid to $500 \mathrm{mg}$ of powder sample and incubated in a digestion hood overnight. The next day, samples were wet digested (HNO3: $\left.\mathrm{HClO}_{4} ; 4: 1\right)$ and in the extracts zinc concentration was measured by using atomic absorption spectrophotometer GBC Avanta Ver 2.02 Model. Zinc content was expressed in parts per million (ppm). Zinc efficiency can be determined as the ratio of shoot dry matter yield produced under $\mathrm{Zn}$ deficiency to that produced under $\mathrm{Zn}$ sufficient condition (Graham et al., 1992).

Fisher's method of analysis of variance was applied for the analysis and interpretation of the experimental data as suggested by Panse and Sukhatme (1967). The level of significance used in ' $F$ ' and ' $t$ ' test was $\mathrm{P}=0.01$. Critical difference $(\mathrm{CD})$ values were calculated at 1 per cent level, wherever ' $\mathrm{F}$ ' test was significant.

\section{Results and Discussion}

\section{Anti-oxidative enzyme}

Graphical representation (Fig 1.) and from table 46 can be depicted that, SOD $(\triangle$ SOD g protein $\left.^{-1}\right)$ and Peroxidase activity $(\Delta \mathrm{OD} \mu \mathrm{mol}$ $\min ^{-1} \mathrm{~g}$ protien ${ }^{-1}$ ) differed significantly among the zinc treatments, genotypes and their interaction also differed significantly. Significantly higher SOD and Peroxidase activity was observed in zinc sufficient $\left(\mathrm{Zn}^{+}\right)$ hydroponic culture $(12.8$ and 4.21, respectively) over zinc deficient $\left(\mathrm{Zn}^{-}\right)$ hydroponic culture $(10.7$ and 3.55 , respectively).

Among the genotypes, Koorigenellu resulted in significantly higher SOD activity (14.2) 
whereas; Ambemohar-2 recorded significantly higher peroxidise activity (4.44) While, Dodigya (9.3) and Karibatta (3.21) observed to have significantly lower SOD and peroxidise respectively.

Similarly among interactions, Koorigenellu recorded significantly higher SOD activity in hogland solution with zinc sulphate (15.3) whereas; Dodigya was found with significantly lower SOD activity in zinc deficient $\left(\mathrm{Zn}^{-}\right)$hydroponic culture (8.3) followed by MTU-1001 (9.1) and Hugibatta-1 (9.4). With respect to peroxidise activity, Koorigenellu (4.85) and Dambersali (4.85) recorded significantly higher peroxidise activity under zinc sufficient $\left(\mathrm{Zn}^{+}\right)$ hydroponic culture, however significantly lower peroxidise activity was resulted with Karibatta (2.95).

The results obtained in this study indicated that, leaf SOD and peroxidise enzyme activity decreased under $\mathrm{Zn}$-deficient conditions, the reason for this is that $\mathrm{Zn}$ is required as a co factor in the functioning of SOD and peroxidase. Due to this reason a drop could be noticed under deficit conditions and improvement with its supply. Similar results were reported by Zeng et al., (2010), found gradual increase in POD and SOD activity with the increasing plant tissues zinc concentrations. The induction of these enzymes due to high zinc content may play an important role in plant defence, aging and senescence. Which has been observed in overall better growth in zinc applied conditions.

\section{Biochemical}

Table 01 depicted that shoot zinc (ppm) and root zinc $(\mathrm{ppm})$ differed significantly among the treatments, genotypes and similarly interaction between zinc treatments and genotypes was resulted significant.
Zinc sufficient $\left(\mathrm{Zn}^{+}\right)$treatment recorded significantly higher shoot zinc content (10.6) and root zinc (18.8) were resulted by Zinc sufficient condition over zinc deficient $\left(\mathrm{Zn}^{-}\right)$ (9.1 and 15.9, respectively). Among the genotypes, Dambersali was recorded significantly higher shoot zinc content (11.9), however higher root zinc content resulted with Ambemohar-1 (19.5) and Koorigenellu (19.3).

Among interactions, Ambemohar-1 resulted significantly higher shoot zinc content (13.3) and root zinc content (22.0) with zinc sufficient hogland solution. Whereas, significantly lower shoot zinc content was found with genotype BPT-5204, whereas SIRI-1253 (14.7) resulted lower root zinc content in hogland solution without zinc sulphate (6.6).

Sufficient amount of $\mathrm{Zn}$ in solution, could be reason of higher zinc content in shoot which could be attributed to its synergistic effects on the enhancement of root development and facilitated greater absorption of $\mathrm{Zn}$ (Chaudhary and Sinha, 2007). Similar result was reported by Naik and Das (2007) also found similar result. Similarly genotypes showed significant difference with respect to root zinc content. Apart from this, genotypes with higher root length and root weight viz., Dambersalib and Koorigenellu showed higher zinc content in root and shoot. Hence, root traits of these genotypes also contribute for zinc content. The increase in root zinc content may be attributed to increase in root proliferation due to greater availability of the cation zinc which enhanced its uptake from solution through diffusion and mass flow from the immediate vicinity of plant roots. Mehdi et al., (1990) also reported that increase in level of $\mathrm{Zn}$ increases the zinc content of roots. 
Table.1 Effect of zinc on growth parameters in 04 week old seedlings of rice genotypes in the hogland solution culture

\begin{tabular}{|c|c|c|c|c|c|c|c|c|c|c|c|c|c|}
\hline \multirow[t]{2}{*}{ Genotypes } & \multicolumn{3}{|c|}{ SOD $\left(g^{-1}\right.$ protien $\left.^{-1}\right)$} & \multicolumn{3}{|c|}{ POX $\left(\mu \mathrm{mol} \mathrm{min}^{-1} \mathrm{~g}^{-1}\right.$ protein $)$} & \multicolumn{3}{|c|}{ Shoot zinc (ppm) } & \multicolumn{3}{|c|}{ Root zinc (ppm) } & \multirow{2}{*}{$\begin{array}{l}\text { Zinc efficiency } \\
\text { for shoot dry } \\
\text { matter (ZEs) }\end{array}$} \\
\hline & $\mathbf{T}_{1}$ & $\mathbf{T}_{2}$ & Mean & $\mathbf{T}_{1}$ & $\mathbf{T}_{2}$ & Mean & $\mathbf{T}_{1}$ & $\mathbf{T}_{2}$ & Mean & $\mathbf{T}_{1}$ & $\mathbf{T}_{2}$ & Mean & \\
\hline Ambemohar 1 & 11.5 & 15.2 & 13.4 & 3.41 & 4.36 & 3.88 & 10.3 & 13.3 & 11.8 & 17.0 & 22.0 & 19.5 & \\
\hline Koorigenellu & 13.0 & 15.3 & 14.2 & 3.96 & 4.85 & 4.40 & 10.4 & 12.9 & 11.6 & 17.0 & 21.6 & 19.3 & 0.82 \\
\hline Dambersali & 11.6 & 15.1 & 13.4 & 3.85 & 4.85 & 4.35 & 10.7 & 13.1 & 11.9 & 15.7 & 20.0 & 17.9 & 0.79 \\
\hline Kempunellu & 11.9 & 13.9 & 12.9 & 3.05 & 3.97 & 3.51 & 10.4 & 12.6 & 11.5 & 14.9 & 18.5 & 16.7 & 0.84 \\
\hline Dodda Batta & 12.3 & 14.8 & 13.6 & 3.88 & 4.69 & 4.28 & 9.5 & 11.8 & 10.6 & 17.7 & 20.8 & 19.2 & 0.85 \\
\hline Ambemohar 2 & 10.3 & 13.2 & 11.7 & 4.06 & 4.81 & 4.44 & 9.4 & 11.3 & 10.3 & 16.5 & 20.7 & 18.6 & 0.88 \\
\hline Dodigya & 8.3 & 10.3 & 9.3 & 3.06 & 3.52 & 3.29 & 10.5 & 12.1 & 11.3 & 15.0 & 17.6 & 16.3 & 0.90 \\
\hline Laldodki & 10.1 & 12.2 & 11.2 & 3.77 & 4.73 & 4.25 & 9.8 & 11.0 & 10.4 & 16.5 & 18.8 & 17.6 & 0.94 \\
\hline Budda & 10.0 & 12.6 & 11.3 & 3.39 & 4.16 & 3.78 & 10.5 & 12.4 & 11.4 & 16.2 & 19.8 & 18.0 & 0.90 \\
\hline Wari M. S. & 12.0 & 14.2 & 13.1 & 3.86 & 4.65 & 4.25 & 9.4 & 10.4 & 9.9 & 17.0 & 19.1 & 18.1 & 0.88 \\
\hline Champakali & 9.5 & 11.8 & 10.6 & 4.00 & 4.79 & 4.39 & 8.4 & 9.6 & 9.0 & 16.5 & 19.4 & 17.9 & 0.90 \\
\hline Improved chitimutayalu & 11.0 & 12.9 & 11.9 & 3.37 & 3.91 & 3.64 & 10.3 & 11.5 & 10.9 & 16.2 & 18.4 & 17.3 & 0.85 \\
\hline Karibatta & 11.5 & 13.1 & 12.3 & 2.95 & 3.47 & 3.21 & 9.3 & 10.7 & 10.0 & 15.4 & 17.4 & 16.4 & 0.90 \\
\hline Chandibatta & 10.3 & 11.1 & 10.7 & 3.60 & 3.96 & 3.78 & 8.5 & 9.9 & 9.2 & 15.0 & 18.0 & 16.5 & 0.88 \\
\hline Halga & 12.0 & 13.2 & 12.6 & 3.12 & 3.41 & 3.27 & 8.3 & 9.0 & 8.7 & 15.5 & 16.6 & 16.0 & 0.90 \\
\hline Siri1253 & 9.6 & 10.7 & 10.2 & 3.32 & 3.69 & 3.51 & 7.4 & 8.1 & 7.7 & 14.7 & 16.2 & 15.4 & 0.94 \\
\hline Kalanamak & 9.6 & 10.4 & 10.0 & 3.21 & 3.49 & 3.35 & 7.9 & 8.5 & 8.2 & 15.1 & 16.3 & 15.7 & 0.92 \\
\hline Hugibatta-1 & 9.4 & 10.7 & 10.1 & 3.96 & 4.41 & 4.19 & 7.0 & 7.6 & 7.3 & 15.5 & 17.0 & 16.2 & 0.94 \\
\hline MTU1001 & 9.1 & 10.5 & 9.8 & 3.66 & 4.15 & 3.91 & 7.8 & 8.7 & 8.3 & 15.0 & 17.0 & 16.0 & 0.92 \\
\hline BPT5204 & 11.6 & 14.5 & 13.1 & 3.53 & 4.38 & 3.96 & 6.6 & 7.9 & 7.2 & 16.4 & 20.2 & 18.3 & 0.90 \\
\hline Mean & 10.7 & 12.8 & 11.8 & 3.55 & 4.21 & 3.93 & 9.1 & 10.6 & 9.9 & 15.9 & 18.8 & 17.4 & 0.82 \\
\hline For comparing means of & S.Em. \pm & \multicolumn{2}{|c|}{ C.D.@ $5 \%$} & \multicolumn{2}{|c|}{ S.Em. \pm} & C.D. @ $5 \%$ & \multicolumn{2}{|c|}{ S.Em. \pm} & $\begin{array}{c}\text { C.D. @ } \\
5 \%\end{array}$ & \multicolumn{2}{|c|}{ S.Em. \pm} & $\begin{array}{c}\text { C.D. @ } \\
5 \%\end{array}$ & \\
\hline Genotypes (G) & 0.2 & \multicolumn{2}{|c|}{0.8} & \multicolumn{2}{|c|}{0.1} & 0.3 & \multirow{3}{*}{\multicolumn{2}{|c|}{$\begin{array}{l}0.2 \\
0.1 \\
0.3\end{array}$}} & 0.7 & \multirow{3}{*}{\multicolumn{2}{|c|}{$\begin{array}{l}0.3 \\
0.1 \\
0.5\end{array}$}} & 1.2 & \\
\hline Treatments (T) & 0.1 & & .3 & & & 0.1 & & & 0.2 & & & 0.4 & \\
\hline $\mathbf{G} \times \mathbf{T}$ & 0.3 & & .2 & & & 0.4 & & & 1.0 & & & 1.8 & \\
\hline
\end{tabular}


Figure.1 Influence of zinc on shoot growth of rice genotypes in Hogland solution

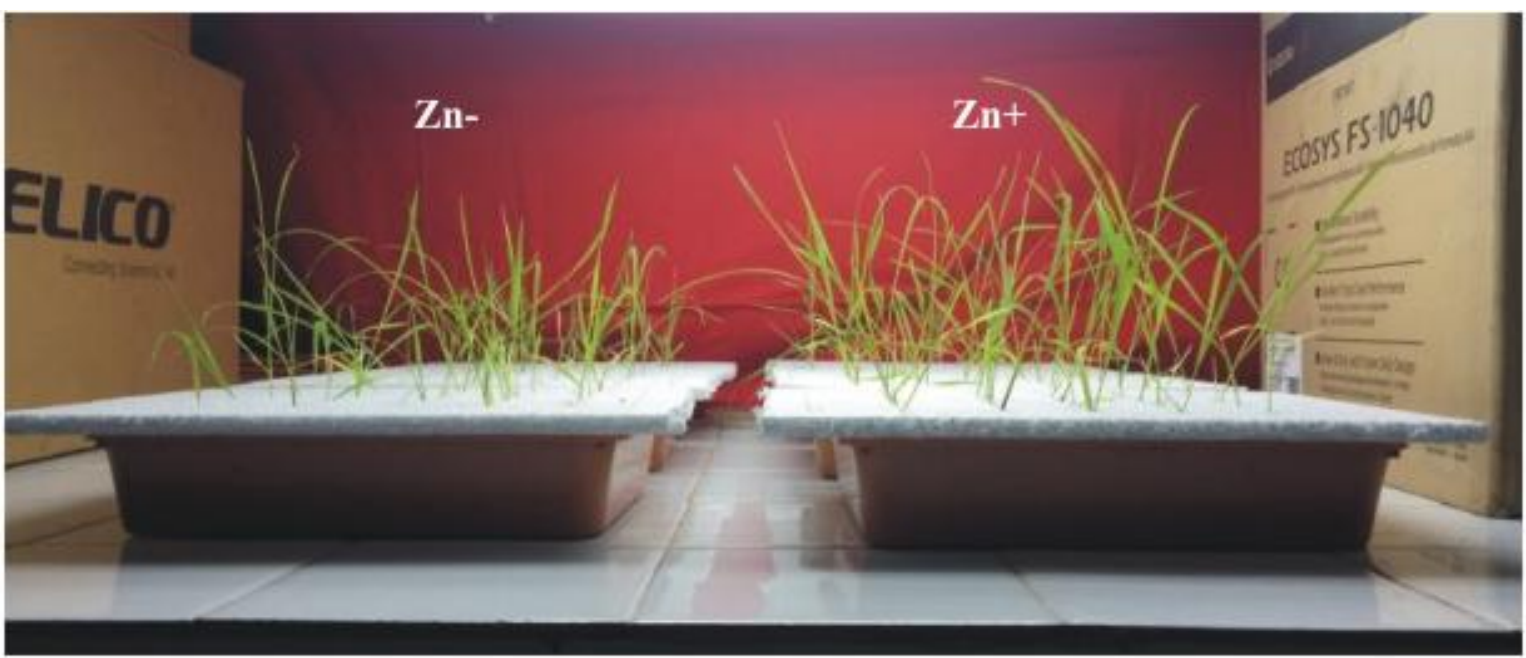

Figure.2 Influence of zinc on root growth of rice genotypes in Hogland solution
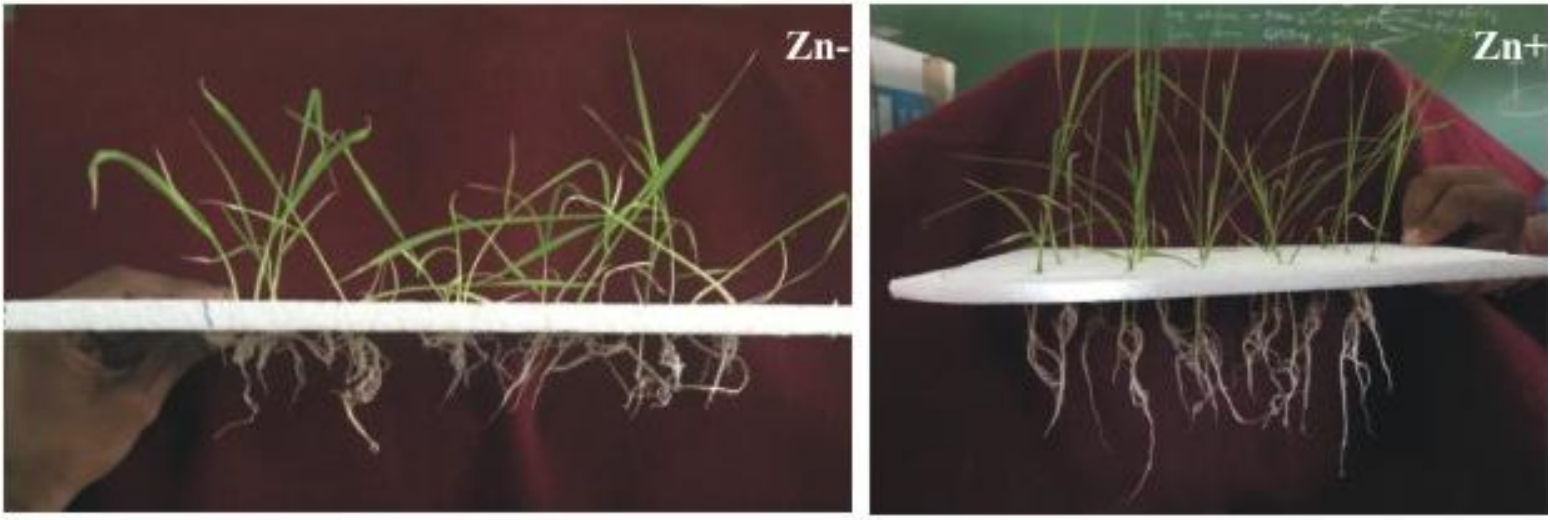

It was concluded from the experiment that 2.0 $\mu \mathrm{M} \mathrm{Zn-sufficient} \mathrm{solution} \mathrm{culture} \mathrm{found} \mathrm{to}$ have beneficial effects on increasing the growth parameters, physiological and zinc content of rice plant.

\section{Zinc efficiency}

Zinc efficiency is defined as the ability of a plant to grow and yield well under zinc deficient condition (Erenoglu et al., 2000). Higher the value of zinc efficiency higher is the growth of the genotype in zinc deficient condition. Response to $\mathrm{Zn}$ deficiency and $\mathrm{Zn}$ fertilization differs greatly among cereals species and genotypes of a given species.

Halga and Kalanamk and Dodigya was recorded as most Zn-efficient genotypes, however Koorigenellu was found as $\mathrm{Zn}$ inefficient genotype with respect to shoot dry weight. $\mathrm{Zn}$-inefficient genotypes are unable to tolerate $\mathrm{Zn}$ deficiency or in other word, they are not efficient to operate mechanisms conferring Zn deficiency tolerance as evident by their significant reduction in root and shoot 
parameters. Whereas, zinc efficient genotypes survive under $\mathrm{Zn}$ deficiency by operating a number of $\mathrm{Zn}$-efficient mechanisms in roots that eventually let these genotypes to continue normal growth and development.

Genotypes, Kalanamak with higher root length were zinc efficient. Hence, from this it can be concluded that higher root length is one of the root trait by which genotypes able to tolerate zinc deficient condition. The genotype, kempunellu which has been found zinc efficient might have root based biochemical mechanisms to survive under zinc deficient condition. Zinc uptake by higher plants appears to be mostly controlled by the transport of zinc across the plasma membrane, which is largely metabolismdependent and genetically controlled. Znefficient genotypes may be able to maintain structural and functional stability of their root-cell plasma membranes better than $\mathrm{Zn}$ inefficient genotypes under $\mathrm{Zn}$ deficiency (Rengel and Graham, 1995).

From this we can conclude that Zinc is very important nutrient for functioning of antioxidative enzymes which necessary for scavenging ROS which are harmful for plant normal functioning. The result of Zinc efficiency showed that genotypes which are zinc efficient survive under $\mathrm{Zn}$ deficiency by operating a number of Zn-efficient mechanisms in roots that eventually let these genotypes to continue normal growth and development, so from this we can improve the root characteristics of genotypes which have traditionally grown under zinc deficiency condition.

\section{References}

Anonymous, 2008, The State of Food and Agriculture 2008. Biofuels: Prospects, Risks and Opportunities, Communication Division Publishers, Rome. pp. 2-85.
Beauchamp, C. and Fridovich, I., 1971, Superoxide dismutase: improved assays and an assay applicable to acrylamide gels. Anal. Biochem., 44: 276-287.

Cakmak, I., Kalayci, M., Ekiz, H., Braun, H.J., Kilinc, Y. and Yilmaz, A., 1999, Zn deficiency as a practical problem in plant and human nutrition in Turkey: a NATOScience for stability project. Field Crop Res., 60: 175-188.

Cakmak, I., Ozturk, L., Eker, S., Torun, B., Kalfa, H. and Yilmaz, A., 1997, Concentration of $\mathrm{Zn}$ and activity of $\mathrm{Cu} / \mathrm{Zn}-\mathrm{SOD}$ in leaves of rye and wheat cultivars differing in sensitivity to $\mathrm{Zn}$ deficiency. J. Plant Physiol., 151: 91-95.

Cakmak, L., Ozuturk, S., Karanli, K. H., Zkaya, O. and Cackmak, I., 2001, Tolerance of 65 durum wheat genotypes to zinc deficiency in a calcareous soil. $J$. Plant Nutr., 240: 1831-1847.

Chaudhary, S. K. and Sinha, N. K., 2007, Effect of levels of nitrogen and zinc on grain yield and their uptake in transplanted rice. Oryza, 44 (1): 44-47.

Dragonuk, M.B., Fehr, W.R. and Jessen, H.J., 1989, Effectiveness of nutrient solution evaluation for recurrent selection for $\mathrm{Fe}$ deficiency of soybean. Crop Sci., 29:952955.

Erenoglu, B., Eker, S., Cakmak, I., Derici, R. and Romheld, V., 2000, Effect of iron and zinc deficiency on release of phytosiderophores by barley cultivars differing in zinc efficiency. J. Plant Nutr., 23: $1645-16565$.

Ger, K.Y., Zhai, F.Y. and Yan, H.C., 1996, The dietary and nutritional status of Chinese Population (1992 National Nutritional Survey). Vol. 1. People's Publishing House, Beijing, pp. 283-311.

Hacisalihoglu, G. and Kochian, L. V., 2003, How do some plants tolerate low levels of soil zinc? Mechanisms of zinc efficiency in crop plants. New Phytologist., 159: 341-350. 
Hacisalihoglu, G., Hart, J. J., Vallejos, C. E. and Kochian, L. V., 2004, The role of shoot localized processes in the mechanism of $\mathrm{Zn}$ efficiency in common bean. Planta., 218: 704-711.

Hacisalihoglu, G., Hart, J.J. and Kochian, L.V., 2001, High- and low-affinity zinc transport systems and their possible role in zinc efficiency in bread wheat. Plant Physiol., 125: 456-463.

Hoagland, D. R. and D. I. Arnon., 1950, The water-culture method for growing plants without soil. California Agric. Exptl. Station Circ., 347: 1-32.

Hotz, C. and Brown, K. H., 2004, Assessment of the risk of zinc deficiency in populations and options for its control. Food Nutrition Bull., 25: 94-204.

Mahadevan, A. and Sridhar, R., 1986, Methods in Physiological Plant Pathology, $3^{\text {rd }}$ Ed. Sivakami Publications, Madras (India), p. 316.

Maret, W., 2009, Molecular aspects of human cellular zinc homeostasis: redox control of zinc potentials and zinc signals. Biometals, 22 (1):149-157.

Mehdi, S. M., Ranjah, A. M. and Hussain, T., 1990, Relatively efficiency of various sources of zinc. Sarhad J. Agric., 6: 103106.

Naik, S. K. and Das, D. K., 2007, Effect of split application of zinc on yield of rice (Oryza sativa L.) in an inceptisol. Arch. Agron. Soil Sci., 53 (3): 305-313.

Pandey, N., Gupta, B. and Pathak, G. C., 2012, Antioxidant responses of pea genotypes to zinc deficiency. Russian $J$. Plant Physiol., 59: 198-205.

Panse, V. G. and Sukhatme, P. V., 1967,
Statistical Methods for Agricultural Workers, ICAR, New Delhi, pp. 167-174.

Prasad.B. and Bose. J.M., 2001, Evaluation of the heavy metal pollution index for surface and spring water near a limestone mining area of the lower Himalayas. Environ Geol. 41:183-188.

Rengel, Z. and Graham, R. D., 1995, Importance of seed $\mathrm{Zn}$ content for wheat growth on Zn-deficient soil. Plant Soil, 173: 267-274.

Rengel, Z., 2001, Genotypic differences in micronutrient use efficiency in crops. Commun. Soil Sci. Pl. Anal., 32: 11631186.

Sakal, R., Sinha, R. B. and Singh, A. P., 1987, Relative performance of mono and hepta hydrate zinc sulphate in calcareous soil. Department of Soil Science, Rajendra Agricultural University, Hyderabad (India). Fert. News., 32: 3-45.

Shankar, A.H. and Prasad, A.S., 1998, Zinc and immune function: the biological basis of altered resistance to infection. Am J Clin Nutr., 68:447S-63S.

Welch, R.M. and Graham, R.D., 2004, Breeding for micronutrients in staple food crops from a human nutrition perspective. J. Exptl. Bot, 55: 353- 364.

Welch, R.M., 2005, Harvesting health, Agricultural linkages for improving human nutrition, micronutrients in south and South East Asia, Nepal. ICIMOD/NARC/UoB, 9-16,

Zeng, B. L., Xiao-Jia, H. E., Lin, C., Lin, T., Shun, G. and Fang, C., 2010, Effects of zinc on growth and antioxidant responses in Jatropha curcas seedlings. Int. J. Agric. Biol., 12: 119-125.

\section{How to cite this article:}

Venkatesh Dore, R.V. Koti and Nawalgatti, C.M. 2019. Influence of Zinc on Functioning of Anti-oxidant Enzymes and Zinc content in Hogland Solution of Rice Genotypes. Int.J.Curr.Microbiol.App.Sci. 8(02): 1227-1234. doi: https://doi.org/10.20546/ijcmas.2019.802.143 